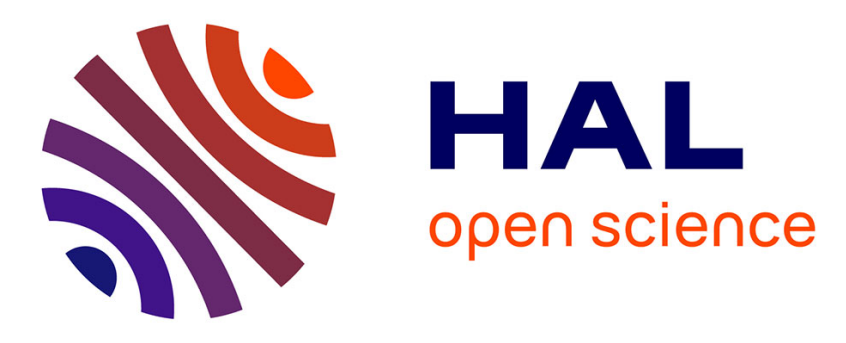

\title{
High Oxidation State Organometallic Chemistry in Aqueous Media: New Opportunities for Catalysis and Electrocatalysis \\ Rinaldo Poli
}

\section{- To cite this version:}

Rinaldo Poli. High Oxidation State Organometallic Chemistry in Aqueous Media: New Opportunities for Catalysis and Electrocatalysis. Chemistry - A European Journal, 2004, 10 (2), pp.332-341. 10.1002/chem.200304810 . hal-03280693

\section{HAL Id: hal-03280693 https://hal.science/hal-03280693}

Submitted on 8 Jul 2021

HAL is a multi-disciplinary open access archive for the deposit and dissemination of scientific research documents, whether they are published or not. The documents may come from teaching and research institutions in France or abroad, or from public or private research centers.
L'archive ouverte pluridisciplinaire HAL, est destinée au dépôt et à la diffusion de documents scientifiques de niveau recherche, publiés ou non, émanant des établissements d'enseignement et de recherche français ou étrangers, des laboratoires publics ou privés. 


\title{
CONCEPT ARTICLE
}

\section{High Oxidation State Organometallic Chemistry in Aqueous Media: New Opportunities}

for Catalysis and Electrocatalysis

\author{
Rinaldo Poli*[a]
}

${ }^{[a]}$ Prof. R. Poli

Laboratoire de Synthèse et d'Electrosynthèse Organométalliques, Université de Bourgogne,

Faculté de Sciences « Gabriel », 6 boulevard Gabriel, 21000 Dijon, France

Fax +33-380393720

E-mail : poli@u-bourgogne.fr 


\begin{abstract}
Molybdenum has been used as a case study for the rational development of a new domain of organometallic chemistry, combining oxo-stabilized high oxidation state metals and aqueous media. The pH-dependent conversion of oxo, hydroxo and aqua ligands allows the opening of free coordination sites, while the use of a redox active metal opens possible pathways for coupled proton and electron transfers to and from activated substrates. While our work has so far only concentrated on synthesis and analytical investigations, the development of catalytic and electrocatalytic processes in water or aqueous media is a promising application of this new research area.
\end{abstract}

Keywords: organometallic chemistry, molybdenum, oxo ligands, aqueous chemistry 


\section{Introduction}

The hydrolytic sensitivity of the metal carbon bond has been a major drawback of organometallic chemistry, forcing the pioneers of this area to develop inert atmosphere techniques and special equipment (e.g. Schlenk tubes) for handling their compounds. This chemistry has consequently been developed, for the most part, in anhydrous organic solvents and has undoubtedly provided the greatest benefit to society through its application to homogeneous catalytic processes. However, the current social and political pressures require us to pay more attention to the environmental impact of chemistry (the concepts of green chemistry and sustainable development) and to develop benign processes that meet stringent environmental criteria. Therefore, the use of water or aqueous media has attracted renewed attention from the organometallic and homogeneous catalysis communities. ${ }^{[1,2]}$ Besides the obvious economical and environmental issues (it is a readily available, inexpensive and non toxic liquid) water also presents other attractive features, such as a higher heat exchange efficiency and the easier separation and recycling of water-soluble transition metal catalysts.

A major trend of organometallic and homogenous catalysis research in aqueous media involves the adaptation of catalysts that have already been found efficient in organic solvents by making them hydrosoluble. This can be easily achieved by the decoration of the outer coordination sphere with substituents that either ionise in water (sulfonates, carboxylates, phosphonates, ammonium, etc.) or establish strong hydrogen bonding interactions in an

aqueous medium (e.g. $\mathrm{OH}, \mathrm{NH}_{2}$, etc.). ${ }^{[3,4]}$ In case the pre-catalyst and all intermediates in the catalytic cycle are hydrolytically stable, the catalytic process will work also in an aqueous medium. All knowledge of chemistry and mechanisms previously acquired from work in 
anhydrous solvents can generally be extrapolated to the aqueous conditions. In several cases, however, organometallic complexes that bear an electric charge (i.e. ionic complexes) are water soluble without the need to use modified hydrophilic ligands. Furthermore, water may act itself as a ligand, as shown by a growing number of organometallic aqua complexes. ${ }^{[5]}$ Catalytic processes operated by these aqua complexes are known, for instance aquaruthenium(II) species catalyze the hydrocarboxylation of ethylene ${ }^{[6]}$ or the olefin metathesis $^{[7]}$ in a fully aqueous solvent.

Most aqueous investigations carried out so far involve low to middle-valent transition metal complexes. Organometallic chemistry in the highest oxidation states has been intensively developed in the last 20 years but most of this research work has been confined to non aqueous media. The greater metal electronegativity in the higher oxidation states confers a greater degree of covalency to the resulting metal-carbon bonds, which consequently may become quite resistant to hydrolytic conditions. It is therefore surprising that the physical behavior and chemical reactivity of high oxidation state organometallics is not systematically investigated in water, although aqueous reagents are sometimes used for their syntheses. Indeed, high oxidation state complexes are often stabilized by the highly $\pi$-donating and electronegative oxo ligand (and also by the isoelectronic imido, sulfido, etc.). An oxo ligand is nothing else than a doubly deprotonated water molecule (Scheme 1) and conventional wisdom tells us that an increase of the metal oxidation state increases the acidity of the oxygen-bound protons, stabilizing the oxo form. Aqua-complexes will be more favored, on the other hand, in the lower oxidation states. Therefore, a redox-active metal offers ways to activate an oxo ligand by transformation to an aqua ligand (a useful source of an open 
coordination site) upon reduction, or to transform a water molecule into a potential oxygen transfer agent upon oxidation.

<insert Scheme 1 here>

The systematic investigation of high oxidation state organometallic complexes in water can therefore open new perspectives for aqueous catalysis and, when a highly redox-active metal is selected, also for electrocatalysis. For instance, substrates that are capable of replacing water in the coordination sphere may become susceptible to accept electrons from the metal and protons from the medium, yielding a hydrogenated product by use of proton and electrons (instead of molecular hydrogen) and regenerating a higher oxidation state oxo or hydroxo complex. Conversely, catalytic oxidations may be achieved by using water as a source of oxygen, by removing protons and electrons.

We have recently initiated a research project having the long term goal of developing new catalytic and electrocatalytic aqueous chemistry with high oxidation state organometallic complexes. The first stage of the project, however, must be a fundamental understanding of the acid/base and redox chemistry of our precursors and of their electrochemically related products in water. Because of our long standing interest in group 6 metals, the subject of most of our first studies has been compound $\mathrm{Cp}^{*}{ }_{2} \mathrm{Mo}_{2} \mathrm{O}_{5}$, a compound which is stable to water and in air. ${ }^{[8]} \mathrm{A}$ related anionic oxo complex of $\mathrm{Cp}^{*} \mathrm{Mo}^{\mathrm{VI}},\left[\mathrm{Cp}^{*} \mathrm{MoO}_{3}\right]^{-}$, had also been previously reported. ${ }^{[9-11]}$ Although some aspects of the synthetic procedures leading to these complexes involve water as a solvent and/or as a reagent, these materials have not been systematically investigated in water. No knowledge was available on the stability of the Cp*Mo bond toward 
hydrolysis, nor on the nature of the $\mathrm{MoO}_{3}$ moiety as a function of $\mathrm{pH}$, nor on the redox properties in water. Organometallic oxomolybdenum compounds of different nuclearity in oxidation states lower than 6 have also been previously investigated, e.g. $\mathrm{Cp}^{*} \mathrm{Mo}^{\mathrm{V}} \mathrm{OCl}_{2}$ and $\left[\mathrm{CpMo}^{\mathrm{IV}} \mathrm{O}\left(\mathrm{PMe}_{3}\right)_{2}\right]^{+}$(mononuclear), ${ }^{[12,13]} \mathrm{Cp}_{2} \mathrm{Mo}_{2}{ }_{2} \mathrm{O}_{4}$ and $\mathrm{Cp}_{2}{ }_{2} \mathrm{Mo}^{\mathrm{IV}}{ }_{2} \mathrm{OCl}_{4}$ (dinuclear), $\left.{ }^{[14,}, 15\right]$ $\left[(\mathrm{Cp} * \mathrm{Mo})_{3}\left(\mu_{2}-\mathrm{OH}\right)_{\mathrm{n}}\left(\mu_{2}-\mathrm{O}\right)_{6-\mathrm{n}}\right]^{2+}(\mathrm{n}=4,5,6)^{[16]}$ and $\mathrm{Cp}_{3} \mathrm{Mo}^{\mathrm{IV}_{3}} \mathrm{OCl}_{7}{ }^{[17]}$ (trinuclear). These compounds, however, have also been mainly investigated in organic solvents and their aqueous chemistry remains largely unexplored.

Another known and interesting high oxidation state organomolybdenum species is $\mathrm{Cp}^{*} \mathrm{Mo}_{6} \mathrm{O}_{18}{ }^{-}$having all Mo center in the oxidation state $\mathrm{VI} .{ }^{[15,18]}$ This can be viewed as an organometallic analogue of the octahedral polyoxomolybdate species $\mathrm{Mo}_{6} \mathrm{O}_{19}{ }^{2-} \cdot{ }^{[19,}$, 20] It is characterized by one terminal $\mathrm{Cp}^{*}$ and five terminal oxo ligands around an oxo-centered octahedral $\mathrm{Mo}_{6} \mathrm{O}_{13}$ cluster. It forms as a by-product during the oxidation of $\left[\mathrm{Cp}^{*} \mathrm{Mo}(\mathrm{CO})_{2}\right]_{2}$ in air and from the condensation between $\mathrm{Cp}^{*} \mathrm{MoO}_{3}{ }^{-}$and $\mathrm{Mo}_{4} \mathrm{O}_{10}(\mathrm{OMe})_{4} \mathrm{Cl}_{2}{ }^{2-}$. Once again, this compound has not been investigated in water.

\section{Nature of $\mathrm{Cp}^{*} \mathrm{Mo}^{\mathrm{VI}}$ in water at pH 0-14}

Previous investigations had indicated that the $\mathrm{Cp}^{*}-\mathrm{Mo}^{\mathrm{VI}}$ bond resists hydrolytic splitting at least down to $\mathrm{pH} 4$, since $\mathrm{Cp}^{*}{ }_{2} \mathrm{Mo}_{2} \mathrm{O}_{5}$ had been obtained in good yields by acidification of an aqueous $\mathrm{Cp}^{*} \mathrm{MoO}_{3}{ }^{-}$solution with acetic acid. ${ }^{[10,11]}$ It would be interesting to establish the $\mathrm{pH}$ limits of this hydrolytic stability. In addition, the mechanism of the above transformation and the stability and physical properties of a putative dioxo-hydroxo intermediate remained 
the matter of speculation. It would furthermore be interesting to know whether other $\mathrm{Cp}^{*} \mathrm{Mo}^{\mathrm{VI}}$ species could exist under any given $\mathrm{pH}$ conditions.

A kinetic investigation using stopped-flow mixing techniques with UV-visible detection has provided much of the missing information. ${ }^{[21]}$ Since $\mathrm{Cp}^{*}{ }_{2} \mathrm{Mo}_{2} \mathrm{O}_{5}$ is insoluble in pure water, the study was conducted in a 80:20 (v/v) water-methanol mixed solvent, but the small amount of alcohol has no effect on the solution chemistry. Acidification of $\mathrm{Cp}^{*} \mathrm{MoO}_{3}{ }^{-}$to $\mathrm{pH}<$ 1 instantaneously and quantitatively yields a new species, assigned to the mononuclear dioxohydroxo complex, which then rapidly and quantitatively (at this $\mathrm{pH}$ ) decomposes to a new species. A spectroscopic analysis of the initial solution as a function of $\mathrm{pH}$ yields the $\mathrm{pK}_{\mathrm{a}}$ of the hydroxo complex $(3.65 \pm 0.02)$. The final product at low $\mathrm{pH}$, however, is not the expected $\mathrm{Cp}^{*}{ }_{2} \mathrm{Mo}_{2} \mathrm{O}_{5}$, but rather a mononuclear cationic complex, $\mathrm{Cp}^{*} \mathrm{MoO}_{2}\left(\mathrm{H}_{2} \mathrm{O}\right)_{\mathrm{n}}{ }^{+}$with $\mathrm{n}=0$ or 1 . Subsequent kinetic and thermodynamics studies under a variety of conditions have allowed the determination of the complete speciation of $\mathrm{Cp}^{*} \mathrm{Mo}^{\mathrm{VI}}$ in this solvent, see Scheme 2. ${ }^{[21]}$

\section{<insert Scheme 2 here>}

These results have several important implications. First, the existence, the thermodynamic stability, the $\mathrm{pK}_{\mathrm{a}}$, and the decomposition mechanism of the $\mathrm{Cp}^{*} \mathrm{MoO}_{2}(\mathrm{OH})$ species are now established. Second, the species $\mathrm{Cp}^{*} \mathrm{MoO}_{2}\left(\mathrm{H}_{2} \mathrm{O}\right)_{n}{ }^{+}$, whose existence was previously unsuspected, turns out to be in fact the only stable form of $\mathrm{Cp}^{*} \mathrm{Mo}^{\mathrm{VI}}$ in a water-rich environment at low $\mathrm{pH}$. Third, the molecular $\mathrm{Cp}^{*}{ }_{2} \mathrm{Mo}_{2} \mathrm{O}_{5}$ compound does not exist as such in this solvent. Instead, it self-ionizes to provide an equal amount of $\mathrm{Cp}^{*} \mathrm{MoO}_{2}\left(\mathrm{H}_{2} \mathrm{O}\right)_{\mathrm{n}}{ }^{+}$and $\mathrm{Cp}^{*} \mathrm{MoO}_{3}^{-}$ions [plus a small percent of neutral $\mathrm{Cp}^{*} \mathrm{MoO}_{2}(\mathrm{OH})$ ] at $\mathrm{pH} 4.1$. It should be 
remarked that this dinuclear compound has been structurally characterized in several different polymorphs, all obtained by crystallization from organic solvents ${ }^{[22,23,24]}$ and all showing a symmetric Mo-O-Mo bridge.

The formulation of the cationic species deserves further comment. The observed first order dependence on $\left[\mathrm{H}_{3} \mathrm{O}^{+}\right]$for the $\mathrm{Cp}^{*} \mathrm{MoO}_{2}(\mathrm{OH})$ decomposition kinetics implies a fast preequilibrium with the conjugate acid, $\mathrm{Cp} * \mathrm{MoO}(\mathrm{OH})_{2}{ }^{+}$, whose $\mathrm{pK}_{\mathrm{a}}$ must be lower than zero, see Scheme 2. This is in agreement with the general knowledge that the two consecutive $\mathrm{pK}_{\mathrm{a}} \mathrm{s}$ of $\mathrm{E}(\mathrm{OH})_{2}$ oxoacids $\left(\mathrm{E}=\right.$ any element, e.g. $\mathrm{S}$ in $\left.\mathrm{H}_{2} \mathrm{SO}_{4}\right)$ usually differ by at least 4 units. The subsequent slow step must be either an intramolecular proton transfer to yield a dioxo-aqua species $($ i.e. $\mathrm{n}=1)$, or water dissociation to yield an unsolvated dioxo complex $(\mathrm{n}=0)$. Either way, the transformation is remarkable because, on the one hand, a tautomerization process exchanging a proton between two oxygen sites is not expected to be such a slow process and, on the other hand, an unsolvated dioxo species is electronically unsaturated (though 5coordinated dioxomolybdenum(VI) complexes are precedented!). ${ }^{[25]}$ Further studies are underway to establish the exact chemical nature of this cationic complex.

Another implication of the $\mathrm{Cp}^{*}{ }_{2} \mathrm{Mo}_{2} \mathrm{O}_{5}$ ionization process is that compound $\mathrm{Cp} * \mathrm{MoO}_{2} \mathrm{Cl}$, another well known complex ${ }^{[22]}$ never previously examined in an aqueous medium, should also ionize in water, see Scheme 3. This has been confirmed by the following additional physical studies. Whereas $\mathrm{Cp}^{*}{ }_{2} \mathrm{Mo}_{2} \mathrm{O}_{5}$ and $\mathrm{Cp}^{*} \mathrm{MoO}_{2} \mathrm{Cl}$ do not conduct electricity when dissolved in all common organic solvents (including pure methanol), the molar conductivity in water-methanol mixtures grows steadily as the percent water increases. The known speciation and thermodynamic parameters (from Scheme 2) lead to excellent fits for the electrical conductivity and $\mathrm{pH}$ as a function of concentration for both $\mathrm{Cp}^{*}{ }_{2} \mathrm{Mo}_{2} \mathrm{O}_{5}$ and 
$\mathrm{Cp}^{*} \mathrm{MoO}_{2} \mathrm{Cl}$, see Figures 1 and 2. ${ }^{[21]}$ Each fit is an independent verifications of the validity of Scheme 2.

<insert Scheme 3, Figures 1 and 2 here>

The speciation shown in Scheme 2 is obviously valid only in the given solvent mixture. Evidence for the presence of higher nuclearity species in methanol-richer mixtures is provided by additional analytical studies (vide infra).

\section{Improved syntheses of (Ring) ${ }_{2} \mathrm{Mo}_{2} \mathrm{O}_{5}$ Compounds}

Our understanding of the nature of $\mathrm{Cp}^{*} \mathrm{Mo}^{\mathrm{VI}}$ in an aqueous solution has led to an improved synthesis of the dinuclear $\mathrm{Cp}^{*}{ }_{2} \mathrm{Mo}_{2} \mathrm{O}_{5}$ compound. Previous reports had shown that $\mathrm{Cp} * \mathrm{MoO}_{2} \mathrm{Cl}$ can be obtained by basic hydrolysis of $\mathrm{Cp}^{*} \mathrm{MoCl}_{4}$ in acetone-water in an open flask, ${ }^{[11]}$ and that the latter is transformed to $\mathrm{Cp}^{*}{ }_{2} \mathrm{Mo}_{2} \mathrm{O}_{5}$ upon treatment with excess $\mathrm{NaOH} .{ }^{[9}$, 11] However, on the basis of our analytical studies detailed above, compound $\mathrm{Cp}^{*} \mathrm{MoO}{ }_{2} \mathrm{Cl}$ should in fact be transformed to $\mathrm{Cp}^{*} \mathrm{MoO}_{3}{ }^{-}$upon treatment with excess aqueous base if the solvent is rich in water. Indeed, the anion is obtained from $\mathrm{Cp}^{*} \mathrm{MoCl}_{4}$ in a one-pot process and, after elimination of by-products, it transforms to $\mathrm{Cp}^{*}{ }_{2} \mathrm{Mo}_{2} \mathrm{O}_{5}$ upon acification. ${ }^{[26]}$ The best results are obtained when only three base equivalents are used initially, to minimize the competitive formation of the $\left[\mathrm{Cp} * \mathrm{MoO}_{2}\right]_{2}$ by-product (which is resistant to aerial oxidation, see Scheme 4). The procedure can be stopped at this point to recover $\mathrm{Cp}^{*} \mathrm{MoO}_{2} \mathrm{Cl}$. Formation of the $\mathrm{Mo}(\mathrm{V})$ product, on the other hand, can be maximized by use of an inert atmosphere and 
four base equivalents. This synthetic strategy has also been extended to systems containing bulkier cyclopentadienyl rings, namely $\mathrm{C}_{5} \mathrm{H}_{2} \mathrm{Bu}_{3}{ }_{3}$ and $\mathrm{C}_{5} \mathrm{HPr}_{4}^{\mathrm{i}}$, whose structure shows a linear and symmetrical Mo-O-Mo bridge like the analogous Cp* compound. ${ }^{[26]}$ A slightly modified synthetic procedure has also allowed an improved synthesis of the unsubstituted $\mathrm{Cp}_{2} \mathrm{Mo}_{2} \mathrm{O}_{5}$ compound.

<insert Scheme 4 here>

\section{Reduction studies by coupled electrochemistry - electrospray ionization mass spectrometry}

In order to evaluate the electrocatalytic potential of the $\mathrm{Cp}^{*} \mathrm{Mo}^{\mathrm{VI}}$ system in water, the electrochemical properties and the nature of the electrogenerated species need to be assessed. Classical electrochemical studies provide no useful information for two reasons: (i) film formation on the electrode surface occurs at $\mathrm{pH}$ greater than ca. 4; (ii) too many concurrent and irreversible reduction processes take place in the same potential region, rendering the data analysis an insurmountable challenge. While the first obstacle can only be avoided by working at low $\mathrm{pH}$, the second one can effectively be surpassed by using a flow-through electrochemical cell, coupled with an on line electrospray ionisation mass spectrometric analysis (ESI-MS) of the reduction products. ${ }^{[27]}$ Electrospray is known as a soft ionization method, but even in this case it is rarely possible to unambiguously establish whether a given species is solution-borne, rather than a fragmentation or condensation product. 
The experiment may be carried out at any desired $\mathrm{pH}$ by use of an appropriate buffer. In our study of the $\mathrm{Cp}_{2}{ }_{2} \mathrm{Mo}_{2} \mathrm{O}_{5}$ reduction, $\mathrm{pH}$ values of 4.0 (acetic acid/acetate) and 1.8 (trifluoroacetic acid) were used. Because of low instrumental sensitivity, a sufficient substrate concentration could only be achieved by using 50:50 methanol/water mixtures, rendering the conditions somewhat different than those of the stopped-flow investigation. This variation, however, provided complementary and useful information. ${ }^{[28,29]}$ The essence of the coupled electrochemistry - mass spectrometry study is as follows. A continuous solution flow is passed through the electrochemical cell via a system of coaxial inlet and outlet capillary tubes whose orifices are in close proximity to the working electrode surface, see Figure 3. Mass spectra are continuously recorded while the potential is scanned at constant rate from an initial to a final chosen value and back, just like in a cyclic voltammetric experiment. The dead time of the transfer line (> $20 \mathrm{~s}$ ) requires, however, very slow scan rates (ca. $0.5 \mathrm{mV} \mathrm{s}^{-1}$ ). As the MS analysis is always carried out on freshly electrolyzed solution, the reverse scan carries no information on chemical dynamics. However, it provides information on the history of the electrode (e.g. film deposition).

<insert Figure 3 here>

A three-dimensional space, namely peak intensities vs. time (or electrode voltage) and vs. $\mathrm{m} / \mathrm{z}$, results from the experiment. The integration of this space in a narrow time (potential) range gives the average MS in the chosen time range (examples are given in Figure 4) whereas integration in a narrow $\mathrm{m} / \mathrm{z}$ range, i.e. a range corresponding to the isotope envelope of a given species, gives the time (potential) evolution of the relative abundance of such species 
(examples are shown in Figure 5 for the starting materials and in Figure 6 for the reduction products).

<insert Figures 4-6 here>

Under open-circuit conditions, the positive ion ESI-MS spectra at pH 4.0 (Figure 4a) and 1.8 show a number of mono-, di-, tri- and even tetranuclear species, including $\mathrm{Cp}^{*} \mathrm{MoO}_{2}{ }^{+}$, $\mathrm{Cp}^{*} \mathrm{MoO}_{3} \mathrm{H}_{2}{ }^{+}, \mathrm{Cp}^{*} \mathrm{MoO}_{2}(\mathrm{MeOH})^{+}, \mathrm{Cp}^{*}{ }_{2} \mathrm{Mo}_{2} \mathrm{O}_{5} \mathrm{H}^{+}, \mathrm{Cp}^{*}{ }_{3} \mathrm{Mo}_{3} \mathrm{O}_{7}{ }^{+}$, and $\mathrm{Cp}^{*}{ }_{4} \mathrm{Mo}_{4} \mathrm{O}_{11} \mathrm{H}_{3}{ }^{+}$. In less straightforward cases, the assignment were confirmed by curve fitting of the isotopic distribution and by collision induced fragmentation $\left(\mathrm{MS}^{2}-\mathrm{MS}^{4}\right)$ studies. At the most negative potential, the mass spectrum (e.g. Figure $4 \mathrm{~b}$ at $\mathrm{pH} 4)$ shows a number of new compounds that result from the electrochemical reduction process, as well as an intensity reduction for the peaks corresponding to the starting material. ${ }^{[29]}$ Studies with negative ion detection mode were also carried out (revealing, for instance, complex $\mathrm{Cp}^{*} \mathrm{MoO}_{3}{ }^{-}$in the starting solution), but gave spectra of lower quality and containing less useful information. The ESI-MS study confirms the presence, in the starting solution, of mononuclear cationic species, as indicated by the stopped-flow and conductivity studies, although is does not demonstrate whether anyone of them is solution borne. Complex $\mathrm{Cp}^{*}{ }_{2} \mathrm{Mo}_{2} \mathrm{O}_{5} \mathrm{H}^{+}$may derive from the proton addition to $\mathrm{Cp}_{2}{ }_{2} \mathrm{Mo}_{2} \mathrm{O}_{5}$, which is certainly present in a $\mathrm{MeOH}$-rich solvent as indicated by the electrical conductivity study (vide supra). Very small (under optimized conditions) amounts of species that manifestly derive from fragmentation processes are also observed. The more surprising finding, however, is the detection of heavier species. Amongst these, at least the trinuclear one is unambiguously solution-borne, as shown by the response to the 
electrochemical reduction, vide infra. A possible structure and formation pathway are proposed in Scheme 5. Therefore, a less water-rich solvent mixture allows the existence of yet novel $\mathrm{Cp}^{*} \mathrm{Mo}^{\mathrm{VI}}$ species. When the water content increases, the greater dielectric constant favors dissociation of this trinuclear ion into the mononuclear species shown in Scheme 2.

\section{<insert Scheme 5 here>}

These plots carry a considerable amount of useful information. The observed decrease after reaching a certain potential value signals the occurrence of an electrochemical process which consumes either the species itself (if this is solution borne) or its precursor (if the species is generated in the mass spectrometer chamber). As shown in Figure 5, the trinuclear species $\mathrm{Cp}_{3}{ }_{3} \mathrm{Mo}_{3} \mathrm{O}_{7}{ }^{+}$is consumed at a less negative potential than the dinuclear and mononuclear species. Therefore, this observation constitutes unambiguous proof that the trinuclear species is not generated by condensation processes from the mono- and dinuclear ones in the MS chamber, and that the equilibrium of Scheme 5 is slow relative to the residence time in the transfer line from the electrode surface to the MS instrument. Thus, $\mathrm{Cp}^{*}{ }_{3} \mathrm{Mo}_{3} \mathrm{O}_{7}^{+}$ must be a solution-borne species.

The MS identification and the time evolution plots of each individual reduction product carry the most valuable information of this experiment. Selected species observed during the experiment at $\mathrm{pH} 4$ are shown in Figure 6. ${ }^{[28]}$ With the exception of $\mathrm{Cp}^{*}{ }_{2} \mathrm{Mo}_{2} \mathrm{O}_{4} \mathrm{H}^{+}$, which is the protonated version of the known ${ }^{[30]} \mathrm{Cp}^{*}{ }_{2} \mathrm{Mo}_{2} \mathrm{O}_{4}$, all observed products are unprecedented. Their detection by this technique means that they survive under the given experimental conditions at least on the minute time scale. Therefore, the power of this analytical technique 
in terms of identifying new synthetic targets can immediately be appreciated. Other undetected species may, of course, be present in solution. Neutral species are not evidenced by the MS experiment whereas negatively charged species would be revealed by operating in negative detection mode. Species with multiple positive charge have not been detected in our experiments on this precursor, although their presence and rapid equilibria with the observed monocations through coordination/dissociation of the acetate anion or proton dissociation cannot be excluded.

The detailed analysis of the onset reduction potential reveals that, within each nuclearity, lower oxidation state products are obtained at more negative potentials (as expected) and that, within each oxidation state, products of higher nuclearity are obtained at less negative potentials. The latter phenomenon is tentatively attributed to the driving force of the metalmetal bond formation. A few products observed under different $\mathrm{pH}$ conditions are related to each other, such as for instance $\mathrm{Cp}^{*}{ }_{2} \mathrm{Mo}_{2} \mathrm{O}\left(\mathrm{O}_{2} \mathrm{CR}\right)_{3}{ }^{+}\left(\mathrm{R}=\mathrm{CH}_{3}\right.$ at $\mathrm{pH} 4$ or $\mathrm{CF}_{3}$ at $\mathrm{pH}$ 1.8), ${ }^{\text {[29] }}$ but others are not, providing useful information on the reduction mechanism. Related products show a less negative onset potential when the $\mathrm{pH}$ is lower, as expected because the reduction is coupled to the protonation of oxo ligands. The lower $\mathrm{pH}$ conditions also permit a higher degree of reduction. For instance, dinuclear Mo(III) products are obtained at $\mathrm{pH} 1.8$, whereas the reduction stops at the oxidation state IV at $\mathrm{pH} 4$. Analogously, the trinuclear $\mathrm{Cp}_{3}^{*} \mathrm{Mo}_{3} \mathrm{O}_{4}{ }^{+}$(oxidation state +4 ) product is obtained at $\mathrm{pH} 1.8$, see Figure 7, whereas the reduction stops at $\mathrm{Cp}^{*}{ }_{3} \mathrm{Mo}_{3} \mathrm{O}_{6}{ }^{+}$(average oxidation state +5.33 ) at $\mathrm{pH} 4$ at the achievable potentials. It should be noted that all detected products (except those proven by the $\mathrm{MS}^{\mathrm{n}}$ experiments to result from fragmentation processes), contain one $\mathrm{Cp}^{*}$ ligand per Mo atom. 
This shows that, in all compounds, the $\mathrm{Cp} *$ Mo bond resists protonolysis, even under strongly acidic conditions. ${ }^{[31]}$

<insert Figure 7 here>

Although most of the species revealed by this study are unprecedented, related compounds are in most cases known with other ligands. For instance, $\mathrm{Cp} * \mathrm{MoO}\left(\mathrm{O}_{2} \mathrm{CCH}_{3}\right)^{+}$is related to $\mathrm{Cp}^{*} \mathrm{MoOCl}_{2},{ }^{[12]} \mathrm{Cp}^{*} \mathrm{Mo}\left(\mathrm{O}_{2} \mathrm{CCH}_{3}\right)_{2}{ }^{+}$to $\mathrm{Cp}^{*} \mathrm{MoCl}_{2}\left(\mathrm{PMe}_{3}\right)_{2}{ }^{+},{ }^{[32]}$ and $\mathrm{Cp}_{2}{ }_{2} \mathrm{Mo}_{2} \mathrm{O}(\mathrm{OH})\left(\mathrm{O}_{2} \mathrm{CCF}_{3}\right)_{2}{ }^{+}$to $\mathrm{Cp}^{*}{ }_{2} \mathrm{Mo}_{2} \mathrm{OCl}_{3}\left(\mathrm{CO}_{3} \mathrm{H}\right) .{ }^{[15]}$ It can be expected that open coordination sites for substrate coordination are easily made available by dissociation of the anionic ligands, especially in the case of the weaker trifluoroacetate, or by bridge opening processes. The trinuclear " $\mathrm{Cp}_{3}{ }_{3} \mathrm{Mo}_{3}(\mu-\mathrm{O})_{6}$ " core has been described before for the $\left[\left(\mathrm{Cp}^{*} \mathrm{Mo}\right)_{3}\left(\mu_{2}-\mathrm{OH}\right)_{\mathrm{n}}\left(\mu_{2}-\mathrm{O}\right)_{6-\mathrm{n}}\right]^{2+}(\mathrm{n}=4,5,6)$ complexes ${ }^{[16]}$ and for the two related $\mathrm{Cp}^{*}{ }_{4} \mathrm{Mo}_{5} \mathrm{O}_{11}$ and $\mathrm{Cp}_{6}{ }_{6} \mathrm{Mo}_{8} \mathrm{O}_{16}$ clusters containing the same 4-electron $\mathrm{Mo}_{3}\left(\mu_{2}-\mathrm{O}\right)_{6}$ core. ${ }^{[16,33]}$ Compounds whose central core is of the "Cp* ${ }_{3} \mathrm{Mo}_{3} \mathrm{O}_{5}$ " or " $\mathrm{Cp}^{*}{ }_{3} \mathrm{Mo}_{3} \mathrm{O}_{4}$ " type, on the other hand, have not been previously reported. Therefore, the structures assigned to these species, which are based on known inorganic analogues, ${ }^{[34]}$ are to be considered only tentative. The results of this coupled electrochemical - ESI-MS experiment suggest that oxygen transfer processes with intervention of protons and electrons should be relatively easy for these trinuclear clusters. They further show that the available coordination sites are not tightly blocked by the solvent molecules, since no $\left[\mathrm{Cp}^{*}{ }_{3} \mathrm{Mo}_{3} \mathrm{O}_{\mathrm{n}}(\mathrm{S})_{\mathrm{m}}\right]^{\mathrm{z+}}\left(\mathrm{n}=4,5,6 ; \mathrm{S}=\mathrm{H}_{2} \mathrm{O}\right.$ or $\mathrm{MeOH} ; \mathrm{m}$ and $\mathrm{z}=$ any number) complexes have been observed other than the solvent-free monocations shown in Figure 7. A rich aqueous chemistry involving redox processes and substrate coordination and 
activation can now be developed on these complexes, provided that synthetic methods for their selective preparation become available.

\section{Chemical reduction studies}

The next step in our project is to verify whether any species that is observed in the combined electrochemical reduction and ESI mass spectrometric analysis can also be chemically generated and isolated. Our studies have been so far quite preliminary. We have chosen $\mathrm{Zn}$ as the reducing agent for reasons of compatibility with the aqueous methanol medium at low $\mathrm{pH}$. The reduction is sluggish, eventually yielding a blue precipitate in an acetic acid medium at $\mathrm{pH} 4$. This corresponds to diamagnetic $\mathrm{Cp}^{*}{ }_{2} \mathrm{Mo}_{2} \mathrm{O}_{2}\left(\mathrm{O}_{2} \mathrm{CCH}_{3}\right)_{2}$, see Figure $8{ }^{[35]}$ As this is a neutral compound, it is not revealed by the electrochemical/mass spectrometric analysis. However, a cyclic voltammetric study shows the accessibility of a reversible one-electron oxidation process $\left(\mathrm{E}_{1 / 2}=-0.50 \mathrm{~V}\right.$ in $\left.\mathrm{CH}_{2} \mathrm{Cl}_{2}\right)$, thus proving the existence and stability of the mixed-valence cation $\mathrm{Cp}^{*}{ }_{2} \mathrm{Mo}_{2} \mathrm{O}_{2}\left(\mathrm{O}_{2} \mathrm{CCH}_{3}\right)_{2}{ }^{+}$which is observed by ESI-MS (Figure 6). The structure shows two oxo and two acetato groups bridging the two metal atoms that are, in addition, held together by a direct metal-metal interaction (Mo-Mo: 2.5524(3) $\AA$ ). This structure is typical of dinuclear cyclopentadienylmolybdenum(IV) species, for instance $\left[\mathrm{Cp}^{\prime} \mathrm{Mo}(\mathrm{S})(\mathrm{SMe})\right]_{2}$ and similar derivatives, ${ }^{[36]}$ but it is the first reported case which is fully supported by O-donor ligands. It can be considered as an example of a stabilized aqueous $\mathrm{Cp}^{*}{ }_{2} \mathrm{Mo}_{2} \mathrm{O}_{2}{ }^{2+}$ species. 
The analogous reduction at lower $\mathrm{pH}$ (trifluoroacetic acid) leads to similar color changes and to the crystallization of different trinuclear complexes depending on conditions. From THF-heptane, a compound that can be formulated as $\left[\mathrm{Cp}^{*}{ }_{3} \mathrm{Mo}_{3}(\mu-\mathrm{O})_{6-n}(\mu-\mathrm{OH})_{n}\right]^{2+} \mathrm{x} 2$ $\mathrm{CF}_{3} \mathrm{COO}^{-}$was obtained. High disorder in the trifluoroacetate and $\mathrm{Cp}^{*}$ fragments limits the precision of the structural results (notably the value of $n$ cannot be determined with confidence), but the basic equilateral triangular $\mathrm{Cp}_{3}{ }_{3} \mathrm{Mo}_{3}(\mu-\mathrm{O})_{6}$ core (Mo-Mo: $2.79 \AA$ ) and the trifluoroacetate arrangement as depicted schematically in Figure 9 are shown unambiguously by the data refinement. ${ }^{[37]}$ The two trifluoroacetate ions establish close contacts between both oxygen atoms and different $\mu$-oxo ligands above and below the $\mathrm{Mo}_{3}$ triangle, the $\mathrm{O} \cdot \mathrm{O}$ distance being typical of hydrogen bonds $(2.6 \AA)$. Therefore, the value of $n$ in the chemical formula is most likely 4 , corresponding to an average oxidation state of +4.33 for the metal atoms. It is relevant to note that a related structure, also characterized by severe disorder, has previously been reported for a compound formulated as $\left[\mathrm{Cp}_{3}^{*} \mathrm{Mo}_{3}(\mu-\mathrm{O})_{6-n}(\mu-\mathrm{OH})_{n}\right]^{2+} \times 2 \mathrm{Cl}^{-}$, this being obtained by a synthetic strategy similar to ours (zinc reduction of $\mathrm{Cp}^{*} \mathrm{MoO}_{2} \mathrm{Cl}$ in $\mathrm{CHCl}_{3}$ in the presence of concentrated $\left.\mathrm{HCl}\right){ }^{[16]}$ In that case, the most likely value of $n$ was proposed as 5 .

<insert Figure 9 here>

Crystallization from THF-diethyl ether, on the other hand, yielded a different compound, $\left[\mathrm{Cp}_{3}{ }_{3} \mathrm{Mo}_{3}\left(\mu_{3}-\mathrm{O}\right)(\mu-\mathrm{O})_{3}\left(\mu-\mathrm{O}_{2} \mathrm{CCF}_{3}\right)_{3}\right]_{2}\left[\mathrm{Zn}_{2}\left(\mathrm{O}_{2} \mathrm{CCF}_{3}\right)_{6}\right]$. The structure of the unprecedented trinuclear monocation is shown in Figure $10 .{ }^{[38]}$ No trinuclear Mo complex, either with or 
without $\mathrm{Cp}^{*}$ ligands, in an oxidation state as high as +5 has been previously reported. The $\mathrm{Mo}_{3} \mathrm{O}_{4}$ core is typical of the oxidation state +4 , and few examples in more reduced states are also known, but none in higher ones. ${ }^{[34]}$ The isolation of trinuclear complexes containing either the $\mathrm{Mo}_{3} \mathrm{O}_{6}$ or the $\mathrm{Mo}_{3} \mathrm{O}_{4}$ core from the same reductive procedure confirms the notion that these species may be easily interconverted via acid/base equilibria involving oxo/hydroxo/aqua tranformation coupled with water dissociation/association equilibria. Furthermore, the anions provided by the supporting acid, especially the weakly coordinating trifluoroacetate ion, may also establish facile association/dissociation equilibria. However, selective synthetic methods for each of these stoichiometries remain to be optimized before detailed analytical speciation and redox studies as a function of $\mathrm{pH}$, as well as subsequent substrate activation studies, may be carried out.

\section{<insert Figure 10 here>}

It is clear that this promises to be an extremely rich chemistry and the synthetic studies that we have carried out so far have probably just uncovered the tip of the iceberg. Besides acid/base and redox equilibria, a wealth of compounds where the bridging oxo/hydroxo ligands are replaced by ligands based on other donor atoms, an example being provided by the known $\left[\mathrm{Cp}^{*}{ }_{3} \mathrm{Mo}_{3} \mathrm{~S}_{4}\right]^{+}$complex, ${ }^{[39]}$ may also be reasonable synthetic targets.

\section{Conclusion and perspectives}


The systematic study of high oxidation state organometallic compounds in water has not so far attracted a lot of attention. Our studies outlined here and the large availability of organometallic oxo complexes for a variety of metals (especially Ta, W, Re and Os) and supporting organic ligands (mostly modified cyclopentadienyl rings and alkyls) provides hope for significant advances in this new area of chemistry in the years to come. The opportunities for chemical research encompass fundamental studies of the synthesis, characterization, redox and speciation of novel compounds, as well as coordination/activation chemistry and catalysis in water. It must be pointed out that, relative to inorganic analogues, the organometallic complexes have a number of coordination positions blocked by the robust, covalent M-R bonds (this is especially true for CpM-based complexes). Consequently, they exhibit a better defined coordination environment which limits or avoids oligomerization/polymerization phenomena and makes model and mechanistic studies more easily approachable. We look forward to significant results in this area, especially from studies of substrate activation, catalysis and electrocatalysis.

\section{Acknowledgement}

Different aspects of this research have been financially supported by the CNRS, the French Ministry of Education, the Conseil Régional de Bourgogne, the French and German Ministries of Foreign Affairs (bilateral Procope program), the French Embassy in Israel (bilateral Arc-enCiel/Keshet program) and NATO/TUBITAK. I have enjoyed fruitful and stimulating collaborations with Prof. H. Sitzmann (Kaiserslautern), Prof. F. Demirhan (Muradiye-Manisa),

Prof. O. Lev and Dr. J. Gun (Jerusalem) and Dr. M. Vorotyntsev (Dijon). I also gratefully 
acknowledge the technical and intellectual contribution of the students, post-docs and permanent staff in my group, whose names appear in the list of references.

\section{References}

[1] P. Kalck, F. Monteil, Adv. Organometal. Chem. 1992, 34, 219-284.

[2] D. Sinou, Topics Curr. Chem. 1999, 206, 41-59.

[3] B. E. Hanson, Coord. Chem. Rev. 1999, 186, 795-807.

[4] C. Muller, D. Vos, P. Jutzi, J. Organometal. Chem. 2000, 600, 127-143.

[5] U. Koelle, Coord. Chem. Rev. 1994, 135, 623-650.

[6] T. Funaioli, C. Cavazza, F. Marchetti, G. Fachinetti, Inorg. Chem. 1999, 38, 33613368.

[7] D. M. Lynn, S. Kanaoka, R. Grubbs, J. Am. Chem. Soc. 1996, 118, 784-790.

[8] M. Herberhold, W. Kremnitz, A. Razavi, H. Schöllhorn, U. Thewalt, Angew. Chem. Int. Ed. Engl. 1985, 24, 601-602.

[9] M. S. Rau, C. M. Kretz, L. A. Mercando, G. L. Geoffroy, A. L. Rheingold, J. Am. Chem. Soc. 1991, 113, 7420-7421.

[10] J. Sundermeyer, U. Radius, C. Burschka, Chem. Ber. 1992, 125, 2379-2384.

[11] M. S. Rau, C. M. Kretz, G. L. Geoffroy, A. L. Rheingold, Organometallics 1993, 12, 3447-3460.

[12] F. Bottomley, P. D. Boyle, J. H. Chen, Organometallics 1994, 13, 370-373.

[13] J. C. Fettinger, H.-B. Kraatz, R. Poli, E. A. Quadrelli, J. Chem. Soc., Dalton Trans. 1999, 497-508.

[14] M. Cousins, M. L. H. Green, J. Chem. Soc. 1964, 1567-1572.

[15] F. Bottomley, J. Chen, Organometallics 1992, 11, 3404-3411.

[16] F. Bottomley, J. Chen, K. F. Preston, R. C. Thompson, J. Am. Chem. Soc. 1994, 116, 7989-7995.

[17] A. Cole, J. C. Gordon, M. A. Kelland, R. Poli, A. L. Rheingold, Organometallics 1992, 11, 1754-1757.

[18] A. Proust, R. Thouvenot, P. Herson, J. Chem. Soc., Dalton Trans. 1999, 51-55.

[19] J. Fuchs, K. F. Jahr, Z. Naturforsch., B: Chem. Sci. 1968, 23, 1380.

[20] M. T. Pope, Heteropoly and isopolyoxometalates, Springer-Verlag, Berlin, 1983.

[21] E. Collange, J. Garcia, R. Poli, New J. Chem. 2002, 26, 1249-1256.

[22] J. W. Faller, Y. Ma, J. Organometal. Chem. 1988, 340, 59-69.

[23] P. Leoni, M. Pasquali, L. Salsini, C. di Bugno, D. Braga, P. Sabatino, J. Chem. Soc. Dalton Trans. 1989, 155-159.

[24] A. L. Rheingold, J. R. Harper, J. Organometal. Chem. 1991, 403, 335-344.

[25] R. H. Holm, J. M. Berg, Acc. Chem. Res. 1986, 19, 363-370.

[26] D. Saurenz, F. Demirhan, P. Richard, R. Poli, H. Sitzmann, Eur. J. Inorg. Chem. 2002, $1415-1424$.

[27] A. D. Modestov, S. Srebnik, O. Lev, J. Gun, Anal. Chem. 2001, 73, 4229-4240. 
[28] J. Gun, A. Modestov, O. Lev, D. Saurenz, M. A. Vorotyntsev, R. Poli, Eur. J. Inorg. Chem. 2003, 482-492.

[29] J. Gun, A. Modestov, O. Lev, R. Poli, Eur. J. Inorg. Chem. 2003, 2264-2272.

[30] H. Arzoumanian, A. Baldy, M. Pierrot, M. Petrignani, J. Organometal. Chem. 1985, 294, 327-331.

[31] We point out, however, that a product of partial $\mathrm{Cp} *$ loss, $\mathrm{Cp}^{*}{ }_{2} \mathrm{Mo}_{6} \mathrm{O}_{17}$, crystallizes upon slow solvent evaporation from an acidic water-methanol solution of $\mathrm{Cp}_{2}{ }_{2} \mathrm{Mo}_{2} \mathrm{O}_{5}$, in air and direct exposure to sunlight, over a long period of time (2 months).

[32] F. Abugideiri, J. C. Fettinger, D. W. Keogh, R. Poli, Organometallics 1996, 15, 44074416.

[33] J. R. Harper, A. L. Rheingold, J. Am. Chem. Soc. 1990, 112, 4037-4038.

[34] D. T. Richens, in The Chemistry of Aqua Ions, J. Wiley \& Sons, Chichester, 1997, pp. 259-336.

[35] F. Demirhan, P. Richard, R. Poli, Inorg. Chim. Acta 2003, 347, 161-166.

[36] M. Rakowski DuBois, M. C. VanDerveer, D. L. DuBois, R. C. Haltiwanger, W. K. Miller, J. Am. Chem. Soc. 1980, 102, 7456-7461.

[37] F. Demirhan, R. Poli, P. Richard, unpublished observations.

[38] F. Demirhan, J. Gun, O. Lev, A. Modestov, R. Poli, P. Richard, J. Chem. Soc, Dalton Trans. 2002, 2109-2111.

[39] P. J. Vergamini, H. Vahrenkamp, L. F. Dahl, J. Am. Chem Soc. 1971, 93, 6327-6329. 


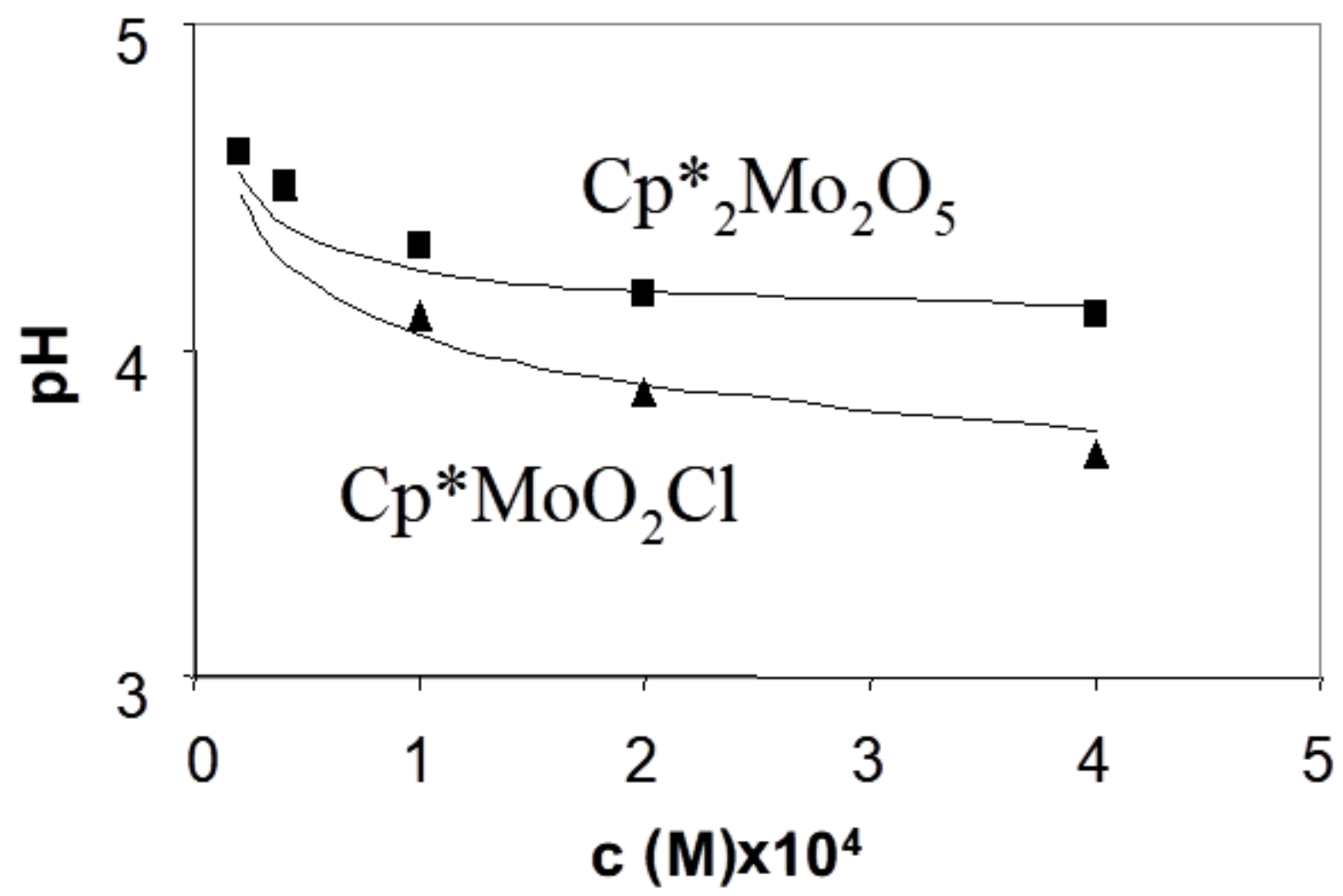

Figure $1 \mathrm{pH}$ of solutions of compounds $\mathrm{Cp}_{2}{ }_{2} \mathrm{Mo}_{2} \mathrm{O}_{5}$ (squares) and $\mathrm{Cp}^{*} \mathrm{MoO}_{2} \mathrm{Cl}$ (triangles) in $20 \% \mathrm{MeOH}-\mathrm{H}_{2} \mathrm{O}$. The curves are calculated on the basis of Scheme 2.

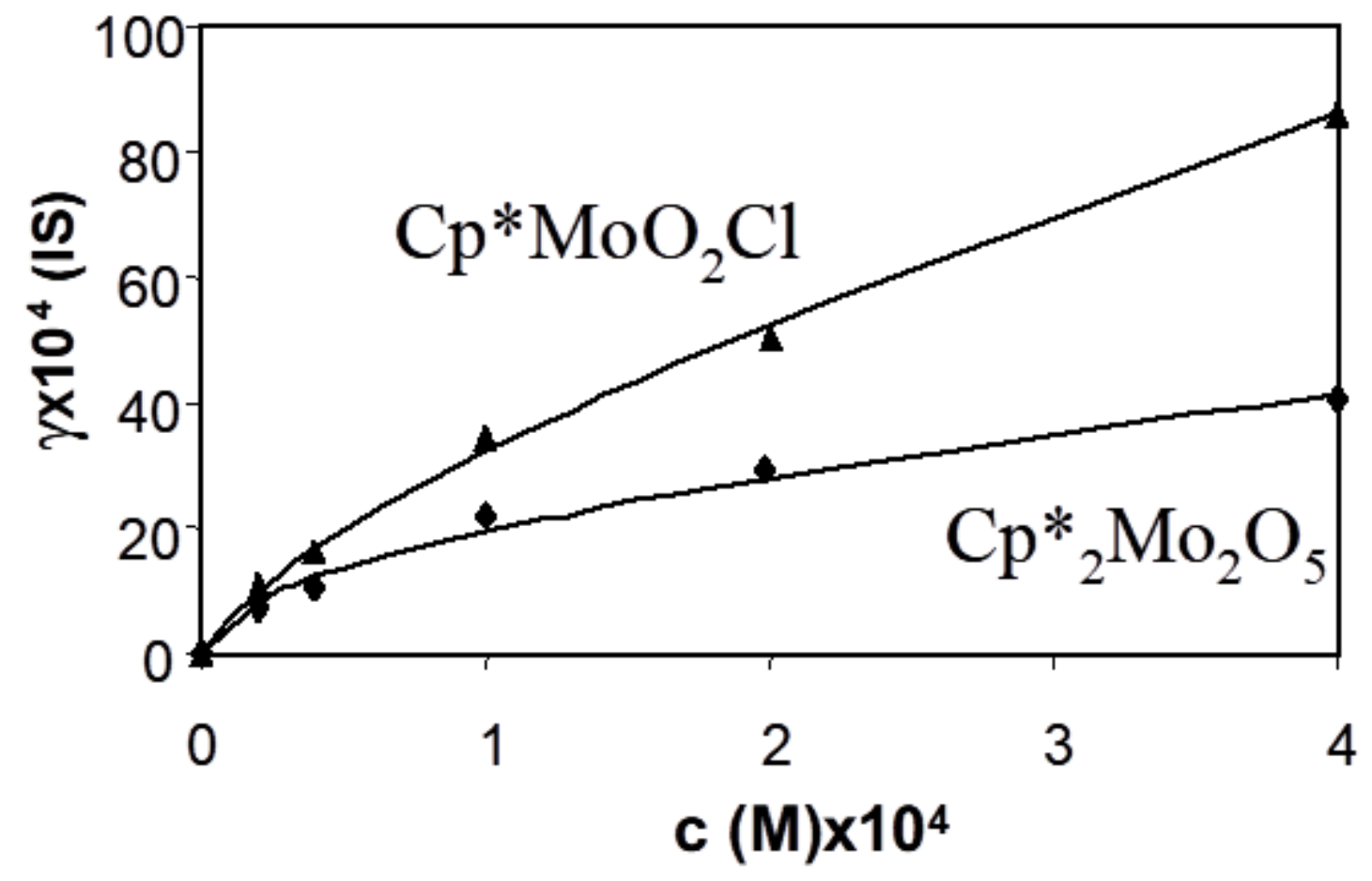


Figure 2 Conductivity of solutions of compounds $\mathrm{Cp}^{*}{ }_{2} \mathrm{Mo}_{2} \mathrm{O}_{5}$ (diamonds) and $\mathrm{Cp}^{*} \mathrm{MoO}{ }_{2} \mathrm{Cl}$ (triangles) in $20 \% \mathrm{MeOH}-\mathrm{H}_{2} \mathrm{O}$. The curves are calculated on the basis of Scheme 2.

\section{to MS}

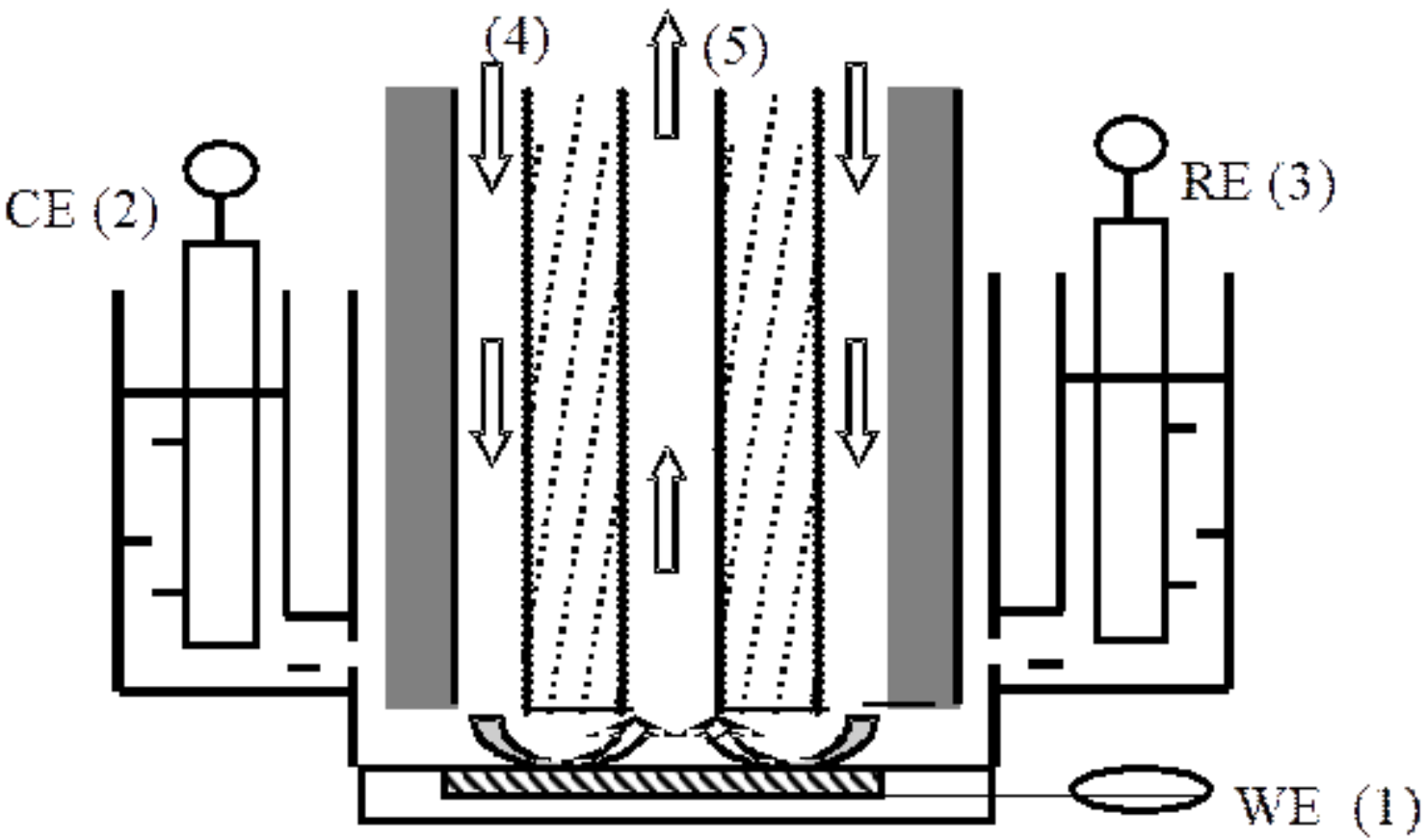

Figure 3 Scheme of the electrochemical cell used. 1 - working electrode (WE); 2 - counter electrode (CE), 3 - reference electrode (RE), 4 - outer capillary (transfer line of reagents to working electrode); 5 - inner capillary (transfer line of products to the $\mathrm{ESI} / \mathrm{MS})$. 

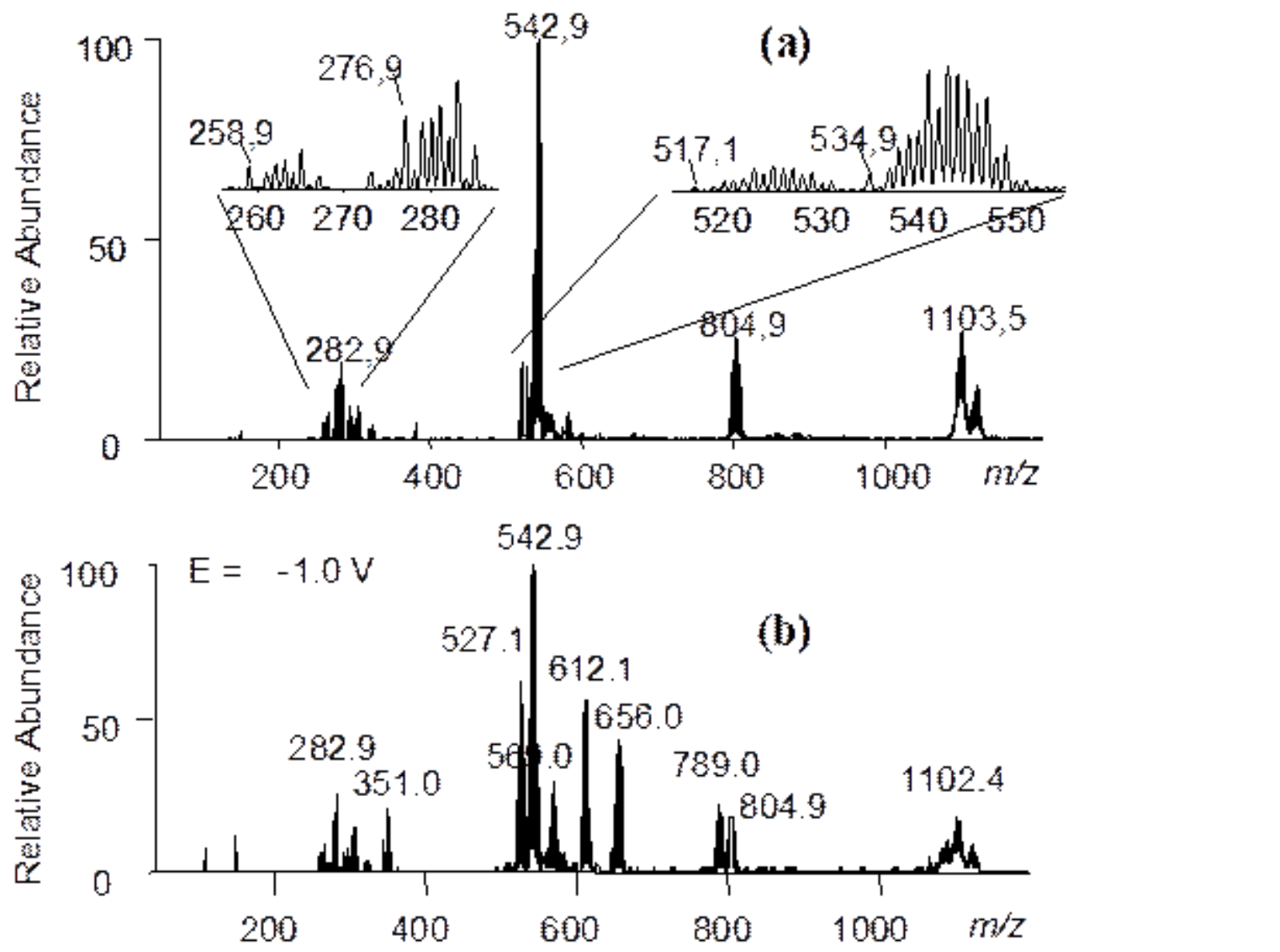

Figure 4 Electrospray mass spectra of a $0.1 \mathrm{mM}$ solution of $\mathrm{Cp}^{*}{ }_{2} \mathrm{Mo}_{2} \mathrm{O}_{5}$ in $\mathrm{H}_{2} \mathrm{O} / \mathrm{MeOH}$ (1:1) at $\mathrm{pH}$ 4. (a) $\mathrm{E}=-0.35 \mathrm{~V}$ (starting potential); (b) $\mathrm{E}=-1.0$ (switching potential). 


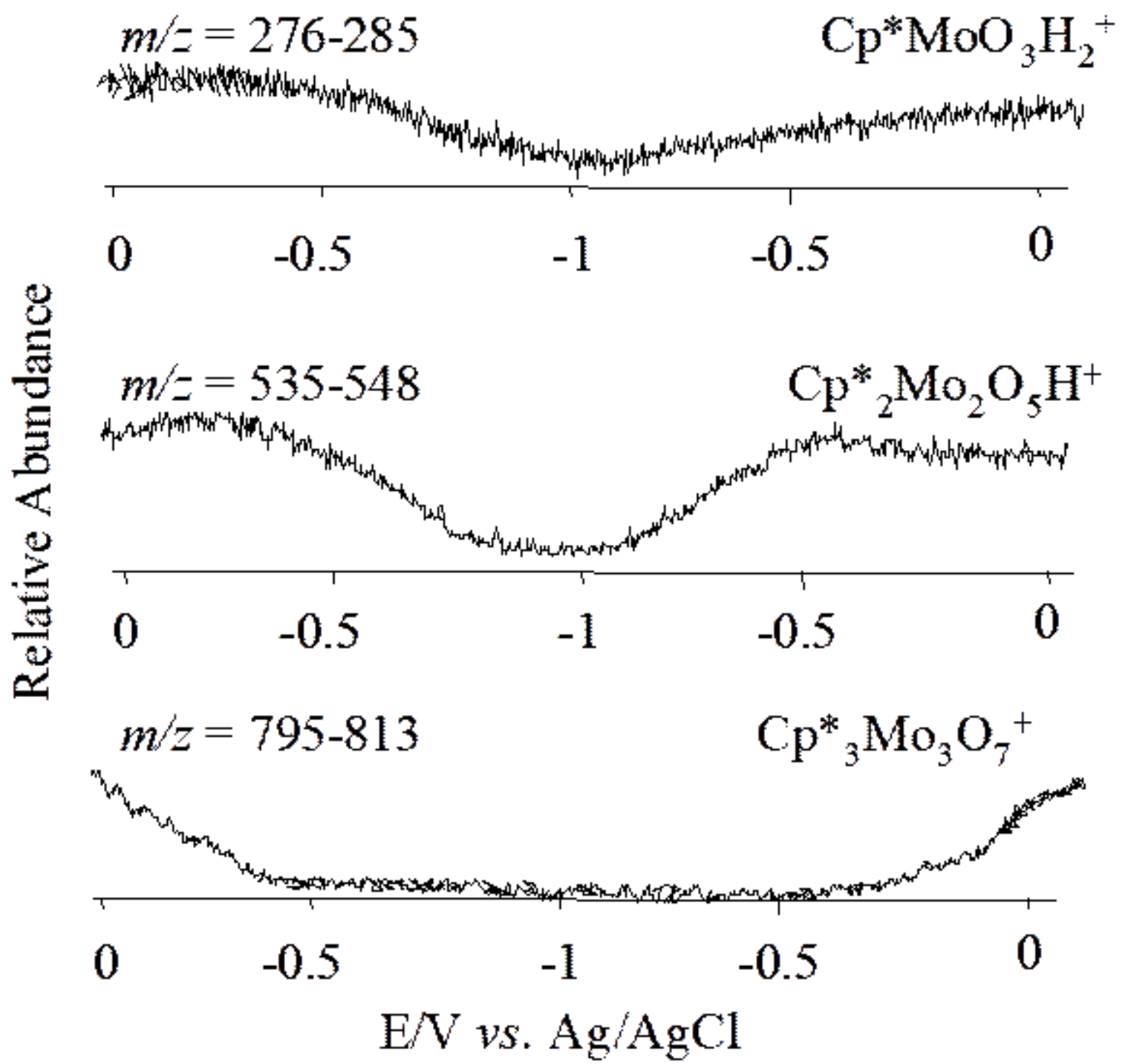

Figure 5 Potential dependent abundance of selected species during a linear potential sweep (scan rate $0.5 \mathrm{mV} \mathrm{s}^{-1}$ from $0.0 \mathrm{~V}$ to $-1.0 \mathrm{~V}$ and back; $\mathrm{pH}=1.8$ ). The $\mathrm{m} / \mathrm{z}$ range used for the integration is indicated above each trace. 
(a) Moncruclear species
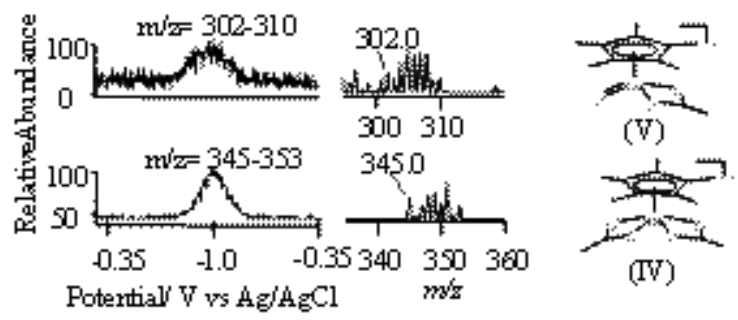

(c) Trivuclear s pecies

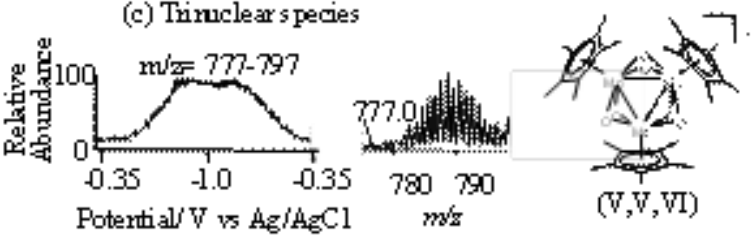

(b) Dirmuclear species
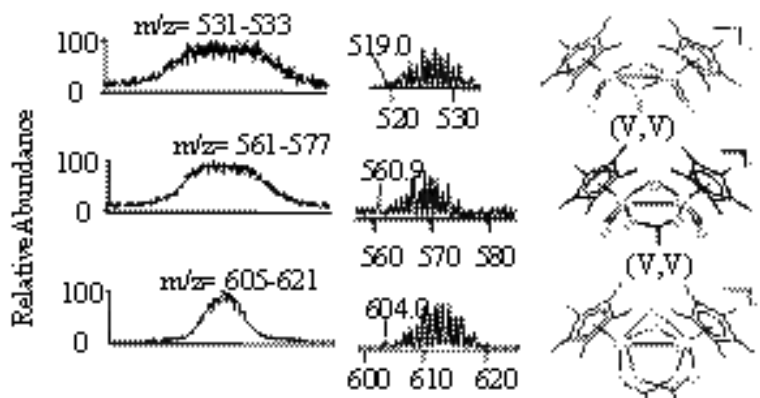

(d) Tetramuclear species
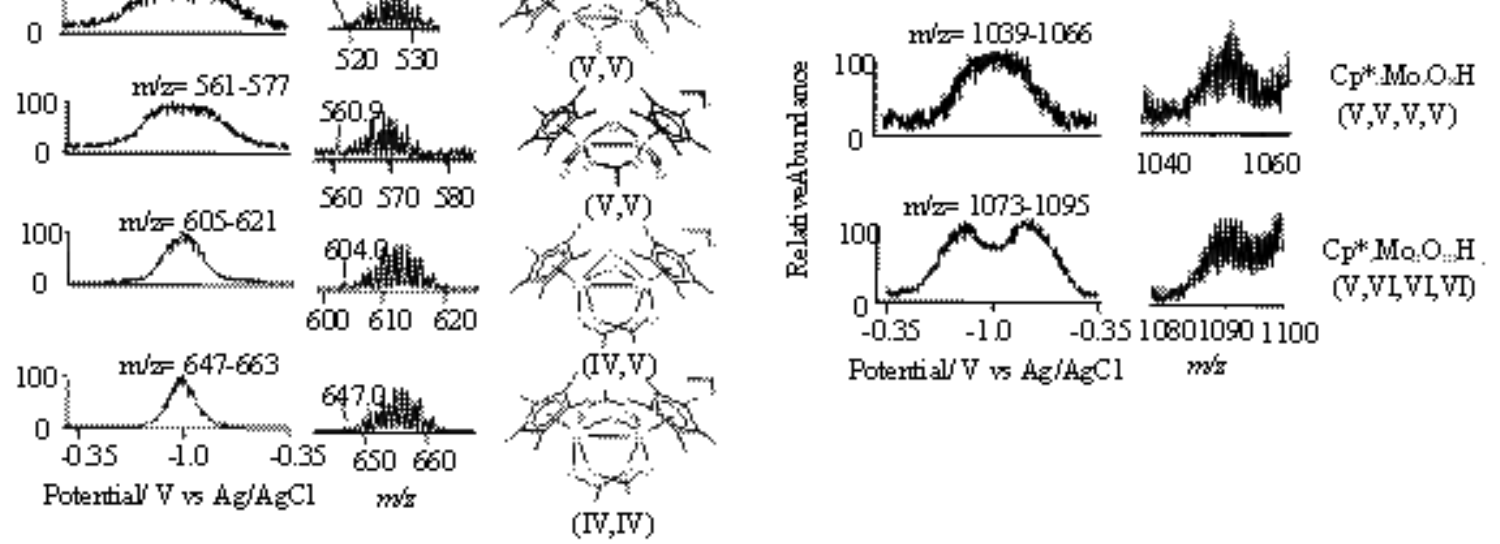

Potertial/ $\mathrm{V}$ v $\mathrm{Ag} / \mathrm{AgCl} \quad \mathrm{m} / \mathrm{z}$

Figure 6 Potential dependent abundance for reduction products formed at $\mathrm{pH} 4$ (left), corresponding isotope envelope (center) and tentative structural formula (right). 
(a) Dinuclear

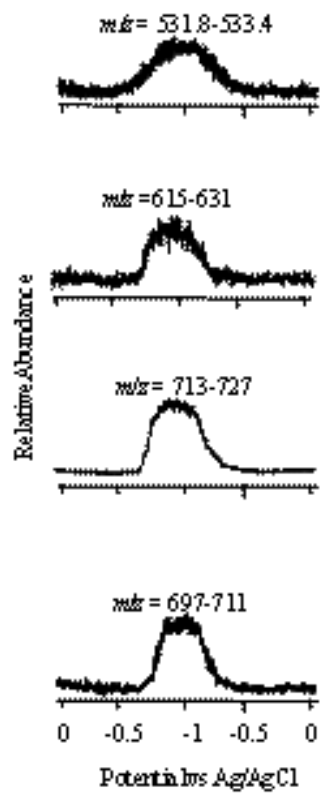

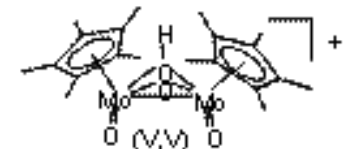
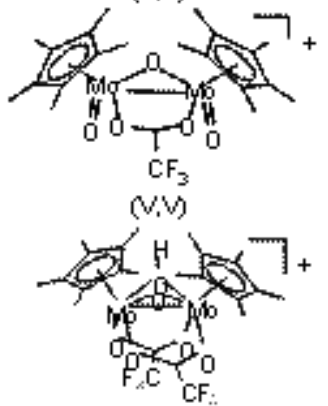

(N,IV)

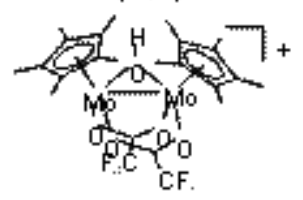

(III, III)

(b)Trinarlear

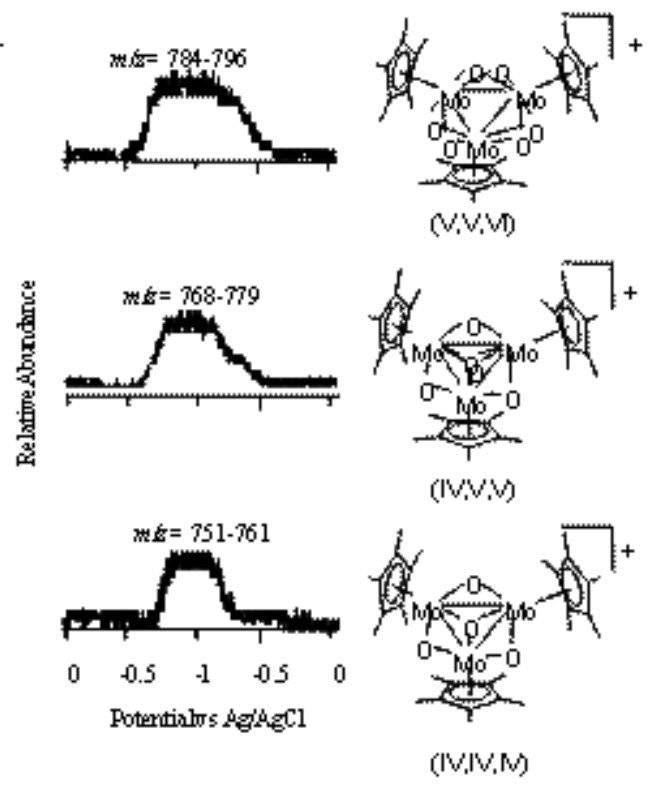

Figure 7. Potential dependent abundance for reduction products formed at $\mathrm{pH} 1.8$ (left), and tentative structural formula (right). The $\mathrm{m} / \mathrm{z}$ integration range in selected cases is limited because of peak overlap. 


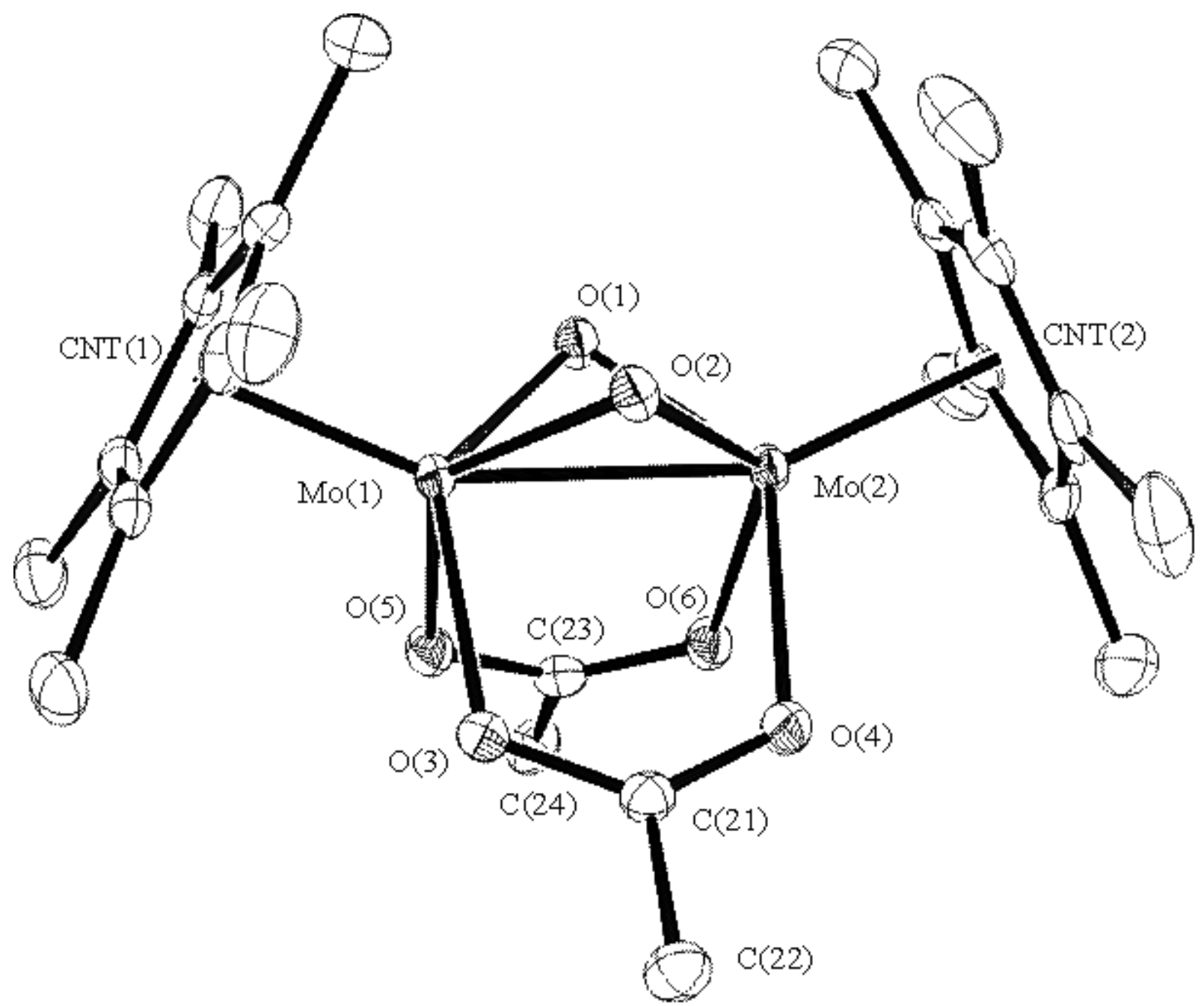

Figure 8 An ORTEP view of the $\mathrm{Cp}^{*}{ }_{2} \mathrm{Mo}_{2} \mathrm{O}_{2}\left(\mathrm{O}_{2} \mathrm{CCH}_{3}\right)_{2}$ molecule. 


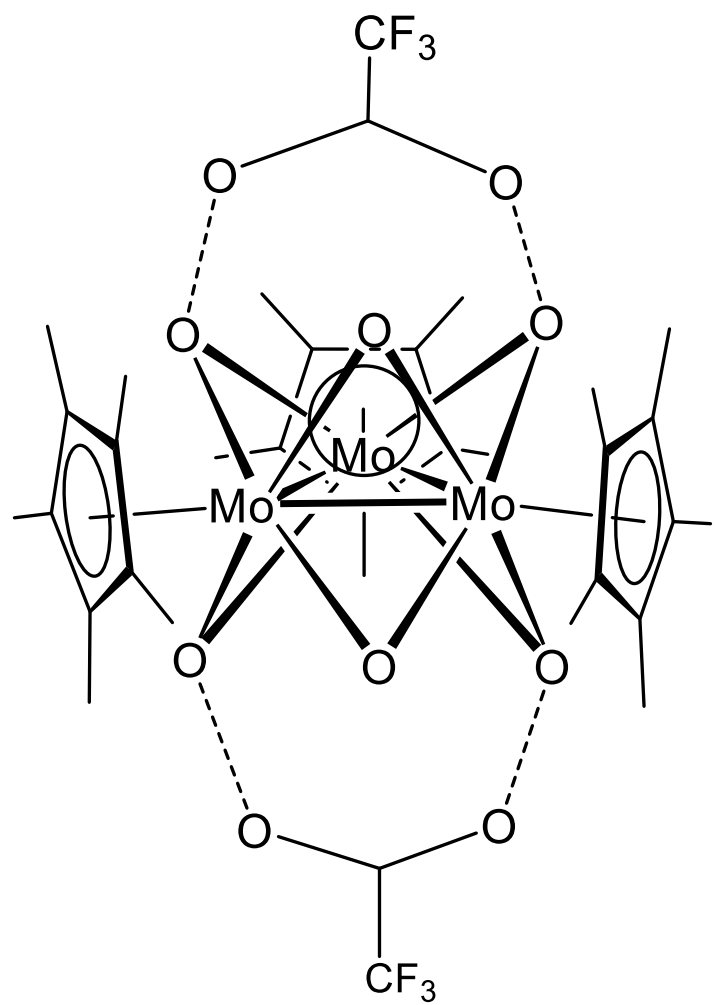

Figure 9 Structural arrangement of compound $\left[\mathrm{Cp}^{*}{ }_{3} \mathrm{Mo}_{3} \mathrm{O}_{6-n}(\mathrm{OH})_{n}\right]\left[\mathrm{CF}_{3} \mathrm{COO}\right]_{2}$ 


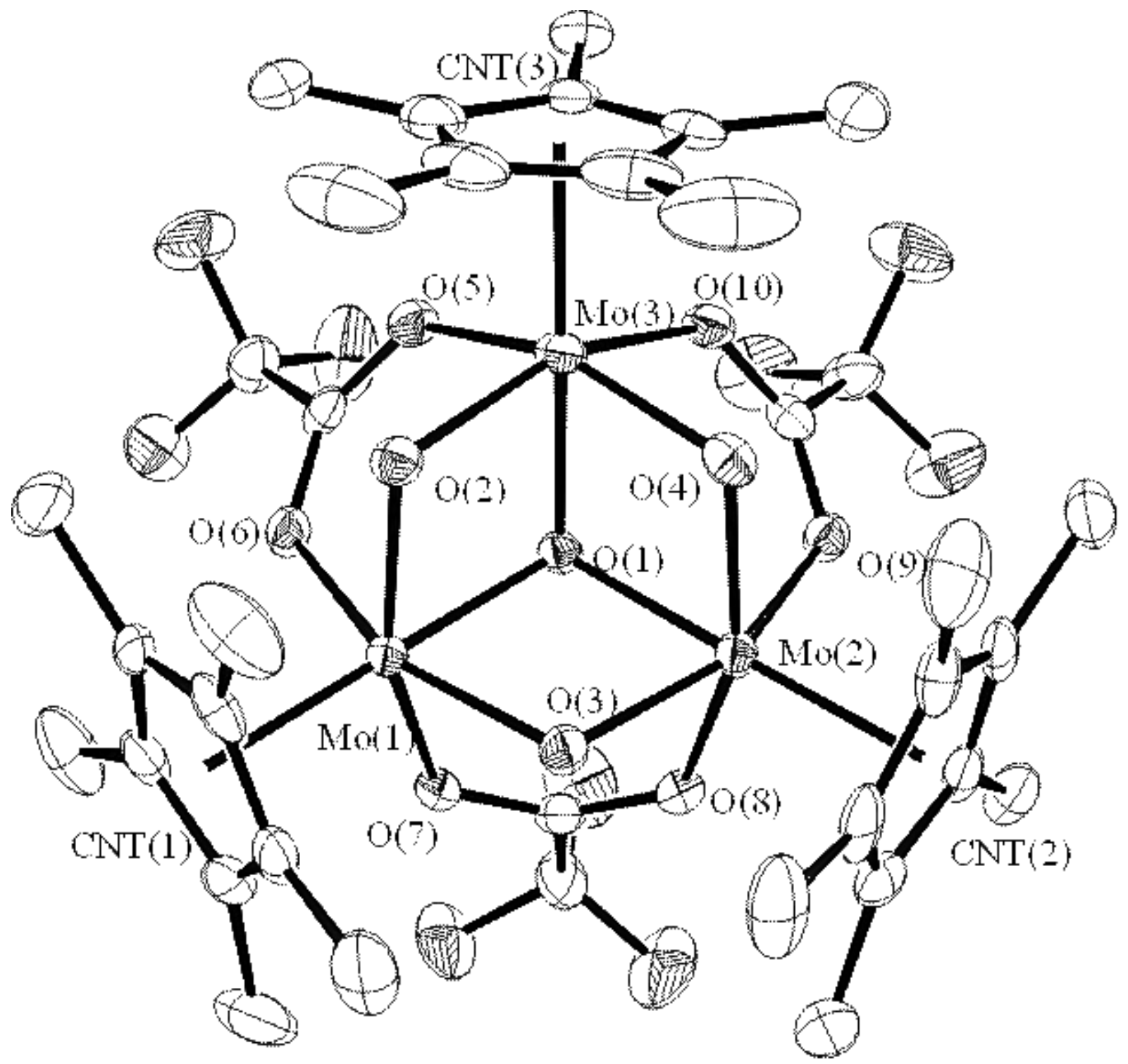

Figure 10 An ORTEP view of the $\left[\mathrm{Cp}^{*}{ }_{3} \mathrm{Mo}_{3}\left(\mu_{3}-\mathrm{O}\right)(\mu-\mathrm{O})_{3}\left(\mu-\mathrm{O}_{2} \mathrm{CCF}_{3}\right)_{3}\right]^{+}$ion. 


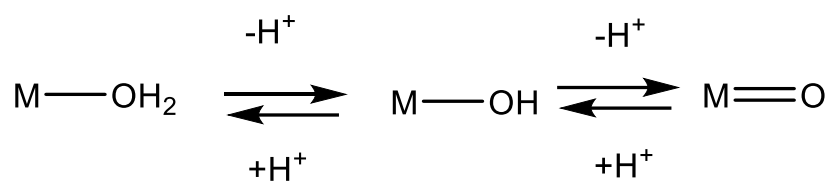

Scheme 1
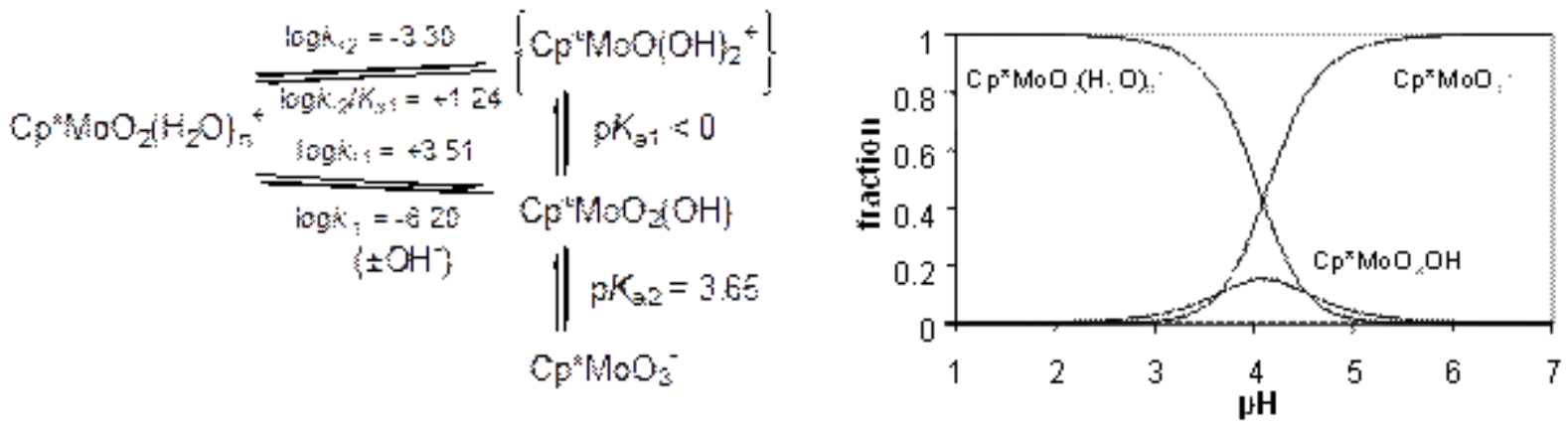

Scheme 2

$$
\begin{aligned}
& \mathrm{Cp}^{*}{ }_{2} \mathrm{Mo}_{2} \mathrm{O}_{5}+\mathrm{n} \mathrm{H}_{2} \mathrm{O} \rightleftharpoons \mathrm{Cp}^{*} \mathrm{MoO}_{2}\left(\mathrm{H}_{2} \mathrm{O}\right)_{\mathrm{n}}{ }^{+}, \mathrm{Cp}^{*} \mathrm{MoO}_{3}{ }^{-} \rightleftharpoons \mathrm{Cp}^{*} \mathrm{MoO}_{2}\left(\mathrm{H}_{2} \mathrm{O}\right)_{\mathrm{n}}{ }^{+}+\mathrm{Cp}^{*} \mathrm{MoO}_{3}{ }^{-} \\
& \mathrm{Cp}^{*} \mathrm{MoO}_{2} \mathrm{Cl}+\mathrm{n} \mathrm{H}_{2} \mathrm{O} \rightleftharpoons \mathrm{Cp}^{*} \mathrm{MoO}_{2}\left(\mathrm{H}_{2} \mathrm{O}\right)_{n}{ }^{+}, \mathrm{Cl}^{-} \rightleftharpoons \mathrm{Cp}^{*} \mathrm{MoO}_{2}\left(\mathrm{H}_{2} \mathrm{O}\right)_{n}{ }^{+}+\mathrm{Cl}^{-}
\end{aligned}
$$

Scheme 3

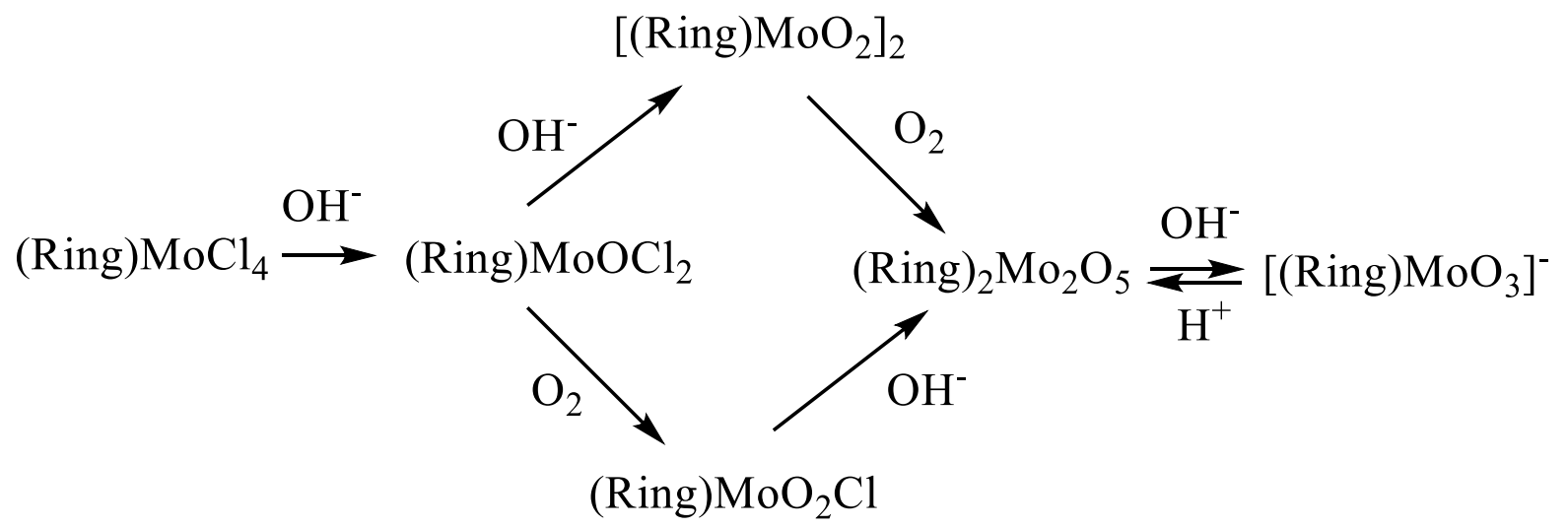

Scheme 4 

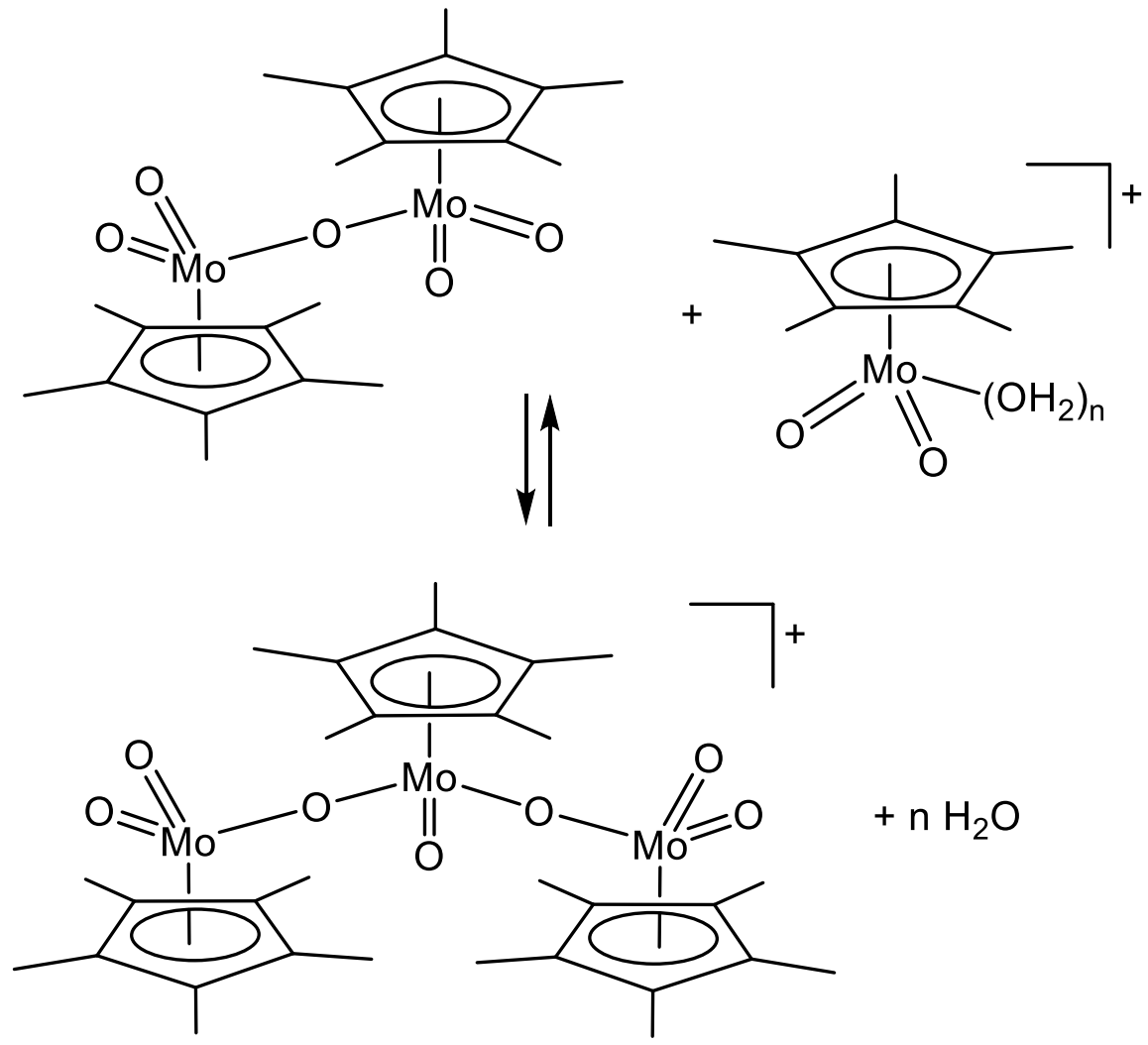

Scheme 5 


\section{For the Table of Content}

Coupling organometallic synthesis with speciation studies at different $\mathrm{pH}$, with stopped-flow kinetics, and with electrochemical experiments in a flow-though cell coupled with electrospray ionization mass spectrometry has revealed the complexity of the aqueous chemistry of the $\mathrm{Cp} *$ Mo species in high oxidation states. A generalization of this approach in high-valent organometallic chemistry holds potential for applications to catalysis and electrocatalysis in aqueous media.

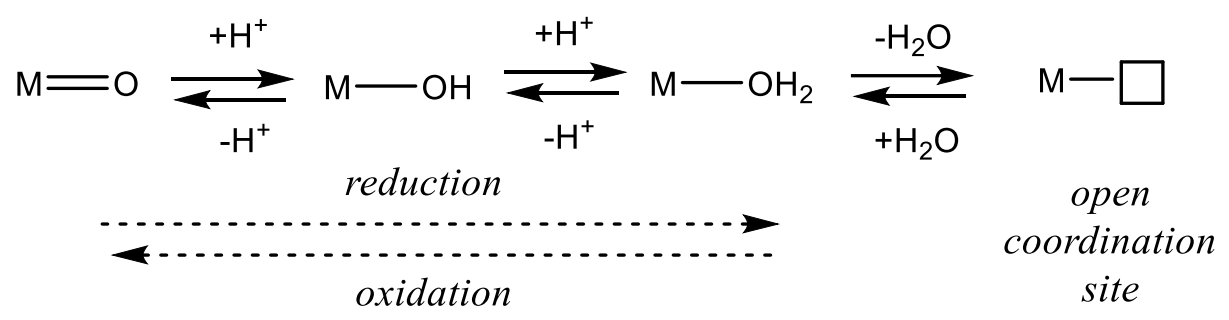

